\title{
CORRESPONDENCE
}

\section{Chronostratigraphic definition of the Precambrian-Cambrian boundary}

SIRS - Current procedures under the auspices of the International Commission on Stratigraphy of the International Union of Geological Sciences (I.U.G.S.) use two contrasting ways of describing major divisions of geological time.

They are:

1. Chronostratigraphy, that defines a scale from continuous rock sequences with standardized reference points in carefully selected and agreed stratotype sections. These complete and internationally acceptable sections with reference to a particular boundary between chronostratigraphic units are global boundary stratotype sections and points.

2. Geochronology, in which a scale (chronometric) is defined and based on units of duration - years or millions of years before the Present (Ma B.P.).

The order of procedure in the Phanerozoic Eon is to establish the chronostratigraphic scale first and then, if possible, to calibrate and correlate it by all available means, including geochronology. (The beginning of the Phanerozoic Eon is here taken to be conterminous with the beginning of the Cambrian Period.) Work towards the definition of the Precambrian-Cambrian boundary has been carried out within the International Commission on Stratigraphy during the last twelve years, and it will also be defined on the chronostratigraphic scale and then correlated, as well as possible, with the chronometric scale.

In the last few years the I.U.G.S. Subcommission on Precambrian Stratigraphy, which is part of the International Commission on Stratigraphy, has proposed that the major units and even periods of the Precambrian Supereon should be defined on the chronometric scale and already the Archaean- Proterozoic boundary has been agreed at $2500 \mathrm{Ma}$.

In 1981 the Chairman of the Subcommission on Precambrian Stratigraphy recorded further provisional recommendations for the chronometric division of the Precambrian. They have not yet been ratified. James (1981) applied a chronometric date of ?570 Ma to the Precambrian- Cambrian boundary in his published table, but the work of the I.U.G.S. Working Group on the Precambrian-Cambrian Boundary makes it clear that this boundary can have only one definition not two - either chronostratigraphic or chronometric - and it has been decided since 1974 that the Working Group will define it chronostratigraphically by a physically fixed basal boundary stratotype point (a 'golden spike') in a section which is globally validated by international agreement. According to this decision of the Working Group made in Paris (France) in 1974 and reaffirmed in Cambridge (U.K.) in 1978 and Bristol(U.K.) in 1983 the Precambrian-Cambrian boundary has to be defined chronostratigraphically: current discussion and voting relates to the selection of the boundary stratotype and does not affect the leading principle of its definition but is concerned with the geological quality and stage of study of the candidates. In other words, the Precambrian-Cambrian boundary can and must be treated in the same way as any other boundary of the Phanerozoic scale: defined by chronostratigraphic criteria only; afterwards it can be calibrated in terms of geochronology.

Current disagreement in the estimation of the chronometric age of most Phanerozoic boundaries (e.g. Odin, 1982; Harland et al, 1982) proves that if the alternative procedure for boundary definition by chronometric data only were to be accepted, then the precision of the chronostratigraphic scale as a tool in correlation would be radically diminished. It is all the more so as far as the Precambrian-Cambrian boundary is concerned, since present estimates of its chronometric age vary over the extreme range of $620-520 \mathrm{Ma}$, which is at least the length of a Phanerozoic Period.

It should be emphasized that following twelve years of effort by the Working Group, the number of candidates voted upon for the Precambrian-Cambrian boundary stratotype was first reduced to three. None of these three was rejected solely because of the lack of, or the quality of, the chronometric information available. It will continue to be a priority task to calibrate the chronostratigraphically defined Precambrian-Cambrian boundary with the chronometric scale, however, as accurately as possible, and studies are currently in progress. Therefore, because the chronostratigraphic definition in certain circumstances allows more precision in correlation than does a chronometric definition, we would continue to apply this method for the definition of successively earlier Precambrian divisions provided their names are distinct from those defined chronometrically. In particular, we advocate that divisions like Vendian, Sinian or whatever names come to be agreed should be defined according to the same principles as for the Cambrian Period and so on backwards in time.

\section{References}

Harland, W. B., Cox, A. V., Llewellyn, P. G., Pickton, C. A. G., SMith, A. G. \& Walters, R. 1982. A Geologic Time Scale. Cambridge University Press, $131 \mathrm{pp}$.

JAMES, H. L. 1981. Reflection on problems of time subdivision and correlation. Precambrian Research 15, 191-8.

OdIN, G. S. (ed.) Numerical dating in stratigraphy. Part I and Part II (2 volumes). John Wiley, 1040 pp

J. W. COWIE Chairman, Precambrian-Cambrian Boundary Working Group, I.U.G.S.; Project Leader I.G.C.P. Project 29 (Precambrian-Cambrian Boundary).

M. G. BASSETT Secretary-General, International Commission on Stratigraphy, I.U.G.S.

W. H. FRITZ Member of the Precambrian-Cambrian Boundary Working Group I.U.G.S.

W. B. HARLAND Member of the PrecambrianCambrian Boundary Working Group, I.U.G.S.

V. V. MENNER Chairman of the National Committee of Soviet Geologists; Vice-President, I.U.G.S.

A. R. PALMER Chairman of the Subcommission on Cambrian Stratigraphy, I.U.G.S.

A. Yu. ROZANOV Vice-Chairman of the Subcommission on Cambrian Stratigraphy, I.U.G.S

M. A. SEMIKHATOV Council member of the U.S.S.R. Geochronological Commission; Vice-Chairman of I.G.C.P. Project 179 (Stratigraphic methods as applied to the Proterozoic).

B. S. SOKOLOV Chairman of the Stratigraphic Committee of the U.S.S.R.

19 April 1984 